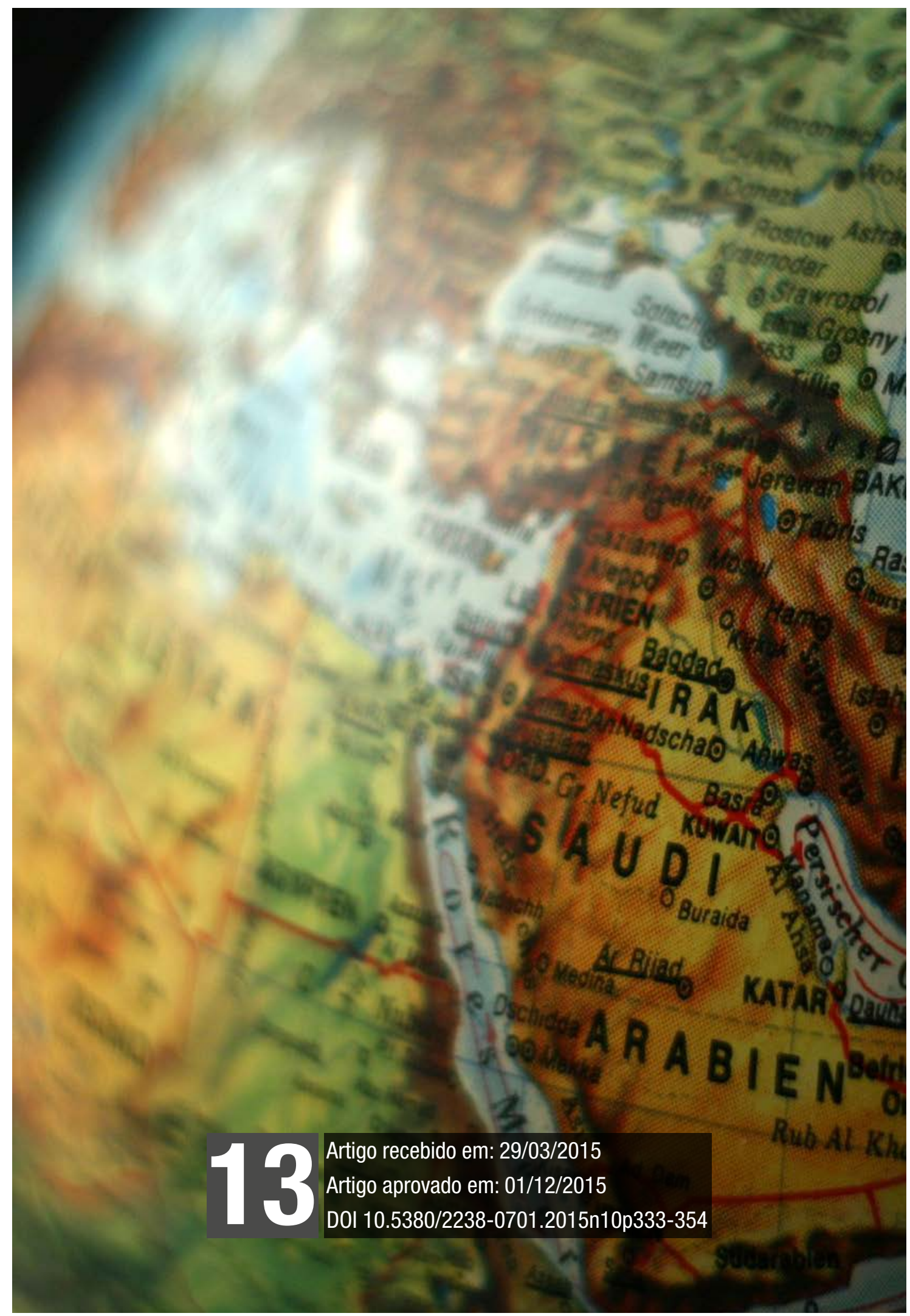


AÇÃO MIDIÁTICA, n. 10. Jul/Dez. 2015. Curitiba. PPGCOM-UFPR. ISSN 2238-0701 


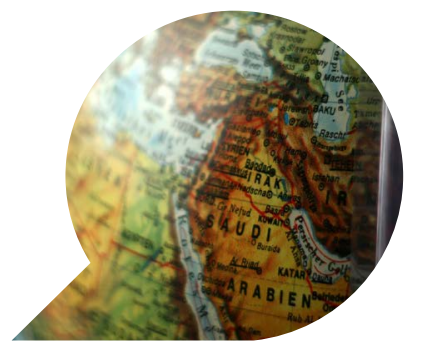

\section{A construção da imagem do "outro": Ocidente e Oriente Médio e suas representações na mídia impressa e na produção audiovisual}

The creation of imaginary about the "other": Middle East and West and its representations in the press and video media.

La construcción de la imagen del "otro": Occidente y el Oriente Medio y sus representaciones en los medios impresos y la producción audiovisual.

\section{LEANDRO ORTUNES}

Resumo: Pretendemos expor neste artigo as várias formas e meios que a construção da imagem sobre a cultura do "outro" é formada. Focaremos nos elementos históricos e atuais que promoveram a construção do imaginário sobre o Oriente Médio no Ocidente e o imaginário sobre o Ocidente no Oriente Médio, ou seja, demonstraremos como ambos se descrevem e são representados nas principais mídias de comunicação. Também descreveremos o contexto histórico em que a imagem sobre os árabes foi drasticamente alterada no Ocidente.

* Doutorando e mestre em Ciências Sociais pela PUC-SP. Especialista em Ciências da Religião (PUCSP) e Relações Internacionais (FAAP). Membro do grupo de pesquisa MIRE (Mídia e Política) da Universidade Metodista de São Paulo, professor universitário na faculdade Estácio de Sá-FNC. E-mail: leandroortunes@uol.com.br 
Palavras-chave: Imaginário; Mundo Árabe; Ocidente; Mídia.

Abstract: This paper describes the various ways and means that the image building on the culture of the "other" is formed. Its focus is on historical and current elements that promoted the construction of the imaginary about the Middle East in the West and the imaginary of the West in the Middle East. Demonstrate how both are described and are represented in the main media of communication. We will also describe the historical context in which the image of the Arabs was drastically altered in the West.

Keywords: Imaginary; Arab World; West; Media.

Resumen: Este artículo describe los distintos modos y medios de que se forma la construcción de la imagen en la cultura del "otro". Su atención se centra en elementos históricos y actuales que promovieron la construcción del imaginario sobre el Medio Oriente en Occidente y el imaginario de Occidente en Oriente Medio. Demostrar cómo ambos se describen y se representan en los principales medios de comunicación. También vamos a describir el contexto histórico en el que la imagen de los árabes fue alterado drásticamente en Occidente.

Palabras clave: Imaginario; Mundo árabe; Occidente; Medios de comunicación. 


\title{
Introdução
}

A construção do imaginário sobre um povo é algo praticamente inevitável quando duas culturas se encontram em determinado momento da história. Este estranhamento é registrado em várias obras que se baseiam em relatos de viagens, cartas enviadas do Brasil colônia para Portugal ${ }^{1}$, diálogos entre índios e descendentes de ingleses nos Estados Unidos ${ }^{2}$, dentre outros. Evidentemente, alguns fatores ampliavam este estranhamento, como exemplo, a dificuldade de comunicação entre as diferentes línguas e pelo distanciamento territorial entre os povos. Embora, atualmente estas barreiras de língua e distância não fossem mais obstáculos como antigamente, ainda percebemos que a criação de um imaginário ainda se faz presente.

Uma das caraterísticas importantes da globalização são os meios de comunicação. O contato online e as informações de várias partes do mundo por meio da imprensa possibilitam maior interação entre pessoas. No entanto, mesmo diante ao fenômeno da globalização, momento em que há uma abertura para o conhecimento de várias culturas, percebemos que o conhecimento sobre o "outro" ainda é algo produzido e reproduzido, e pouco vivenciado ou experimentado. O grande problema é que estas representações podem estar impregnadas de preconceitos, generalizações e distorções de uma determinada cultura.

Uma vez que a mídia é a grande produtora de imaginários e reproduções de certa cultura, a academia e várias áreas das ciências buscam compreender suas implicações e reflexos na sociedade:

\begin{abstract}
A formação da esfera comunicativa moderna, que se estruturou com o nascimento dos modernos meios de comunicação, provocou o surgimento de uma série de fenômenos novos, no contexto dos quais esses meios tornaram-se cada vez mais poderosos, despertando a preocupação das mais diversas disciplinas do conhecimento humano para com a comunicação (RUDIGER, 2011, p.14).
\end{abstract}

Este será nosso principal objetivo neste artigo, demonstrar alguns estereótipos de determinadas culturas criados por outras. Buscaremos demonstrar dois lados desta construção entre Oriente e Ocidente e que, por muitas vezes, é reproduzido na produção 
cinematográfica e na cobertura jornalística. Para desenvolver este trabalho, partimos de uma análise da produção cinematográfica norte-americana e de comerciais de televisão do Irã e Arábia Saudita. Nosso critério de seleção se baseou no documentário Filmes ruins árabes malvados, que descreve a obra do professor Jack Shaheen, da Universidade de Illinois, e no documentário Obsession radical islam war against the west produzido pelo diretor Wayne Kopping. Sobre a cobertura jornalística impressa, analisaremos os dados dos principais jornais do Estado de São Paulo, - Folha de S. Paulo e O Estado de S. Paulo - isso baseado no trabalho da doutora Isabela Somma.

\section{A construção do imaginário sobre o Ocidente e o Oriente Médio}

O estranhamento religioso possui algumas particularidades quando nos referimos às religiões universais como o cristianismo e o islamismo. São religiões consideradas universais devido à ênfase no proselitismo e no caráter universal de sua mensagem, não limitando a uma etnia ou região. Este fato promove um choque religioso, uma vez que as duas religiões disputam fiéis e julgam-se deter a salvação exclusiva. Destacamos que esse choque não pode ser confundido com a violência física, embora algumas vezes isso aconteça. Tal choque é uma resistência em conhecer e compreender alguém que possui valores diferentes da cultura pertencente. Mesmo diante do processo de secularização, esse choque permanece, mas agora assumindo novas características que ultrapassam apenas a questão religiosa.

Partindo para o foco de nosso estudo, o autor Edward Said relata que há uma falta de compreensão do movimento islâmico nos Estados Unidos:

Gostaria de poder afirmar que a compreensão geral do Oriente Médio, dos árabes e do Islã nos Estados Unidos melhorou um pouco. Mas, infelizmente, o fato é que isso não ocorreu [...] Nos Estados Unidos, o endurecimento das atitudes, o estreitamento tenaz ${ }^{3}$ das generalizações desencorajantes e do clichê triunfalista, a supremacia da força bruta aliada a um desprezo simplista pelos opositores e pelos "outros" encontraram um correlativo adequado no saque, na pilhagem e na destruição das bibliotecas e dos museus do Iraque. (SAID, 2007, p.14)

3 Said comenta que os Estados se fecham para um verdadeiro entendimento em relação ao Oriente, restringindo-se as generalizações sobre o tema. 
Para Said, a construção do imaginário sobre o mundo mulçumano não está restrita à mídia, na verdade, a própria academia reproduziu durante séculos imagens equivocadas, e demonstrou uma necessidade de classificar através de termos e conceitos tal cultura:

O orientalismo é o termo genérico que venho usando para descrever a abordagem ocidental do Oriente; é a disciplina por meio da qual o Oriente é abordado sistematicamente, como um tema de erudição, de descobertas e de prática. Mas, além disso, eu tenho usado a palavra para designar aquela coleção de sonhos, imagens e vocabulários disponíveis para qualquer um que tenha tentado falar sobre o que está a leste da linha divisória. (SAID, 2007, p.115)

Há certa confusão até mesmo na definição de alguns termos que acabam promovendo generalizações na mídia e na literatura. Os termos "árabes", "Oriente Médio", "muçulmanos" e "fundamentalismo" são geralmente utilizados como correlatos. No entanto, sabemos que existe grande diferença entre estas palavras e seus significados. Uma pesquisa realizada por Basnyuoni Hamada (2001) trouxe resultados que comprovam a hipótese de que há uma confusão generalizada sobre os termos. Isabelle Soma Castro comenta que em uma entrevista com 118 jornalistas, $40 \%$ deles afirmaram que árabes e muçulmanos são a mesma coisa (CASTRO, 2007, p.33).

Embora os termos árabes e muçulmanos coincidam por muitas vezes, os mesmos não podem ser encarados como sinônimos uma vez que árabe está relacionado a uma identificação étnica e muçulmano a uma identificação religiosa. Vale destacar que neste trabalho utilizaremos a expressão "mundo muçulmano" para descrever nações predominantemente muçulmanas, mas que não necessariamente são da etnia árabe. Podemos também questionar até mesmo o termo usado para definir uma região geográfica que constantemente é vista como uma região extremamente conturbada politicamente:

O próprio termo Oriente Médio, usado para definir a região geográfica que é hoje lar de cerca de 400 milhões de muçulmanos, comporta discussões. O termo (do inglês Middle East) é evidentemente de cunho eurocentrista e data, justamente, do século XIX, época em que o império britânico controlou mares e um quarto da Terra. (DEMANT, 2004, p.15) 
Com isso, já percebemos grandes problemas puramente conceituais sobre o Oriente Médio, mundo muçulmano e mundo árabe. Estes conceitos são utilizados, por muitas vezes, como correlatos sem qualquer distinção ou observações que esclareçam o leitor. Jack Shaheen ${ }^{4}$, professor da Universidade de Illinois, nomeia o Oriente Médio como uma Arabland, região muito diversa, mas que ficou estigmatizada como uma terra desértica, violenta e extremamente religiosa. Utilizaremos este termo para descrever a região do Golfo Pérsico, incluindo Israel e Síria.

\section{A construção do imaginário na produção audiovisual}

Partindo para a construção contemporânea sobre o Oriente Médio, utilizaremos alguns exemplos demonstrados no documentário Filmes ruins árabes malvados ${ }^{5}$. Uma série de estereótipos sobre os árabes recorrentes nos filmes produzidos por Hollywood são apresentados sistematicamente no documentário. Primeiramente, um fato que chama a atenção é a representação do mundo árabe no cinema infantil. O desenho Aladdin, lançado em 1992, possui uma música em sua abertura que provocou grande crítica ao conteúdo da letra. Abaixo traduzimos livremente a versão original em inglês entre 1992 e 1993.

Oh, eu venho de uma terra. De um lugar distante, onde os camelos da caravana percorrem. Onde eles cortam sua orelha se não gosta do seu rosto. É bárbaro, mas, hey, este é o lar.

Devido às críticas, a versão para DVD home, a partir de 1993, foi reeditada e recebeu a seguinte letra:

Oh, eu venho de uma terra, de um lugar distante onde os camelos da caravana percorrem, onde é plana e imensa. E o calor é intenso, é bárbaro, mas hey, ele está em casa.

[...]

Noites na Arábia e o cair da lua árabe. Um tolo desprevenido poderia cair, e cair duro lá fora nas dunas.

4 Autor do documentário Reel Bad Arabs e dos livros The TV Arab (1984) e Arab and Muslim Stereotyping in American Popular Culture (1997).

5 Reel Bad Arabs: How Hollywood Vilifies a People. 2006, 50 min. 
O documentário se detém apenas na primeira versão 1992/1993. Mas com base neste apontamento, buscamos as traduções em português e espanhol para identificarmos se a representação sobre o mundo árabe na música permanece semelhante à primeira versão norte-americana. Na versão em português, encontramos outro termo complicador inserido na letra na música. Além da frase que indica uma mutilação do corpo por um motivo banal (semelhante à primeira versão norte-americana) descobrimos um acréscimo sobre as orgias da Arábia:

Venho de um lugar onde sempre se vê uma caravana passar, vão cortar sua orelha para mostrar pra você como é bárbaro o nosso lar. $[\ldots]$

A noite da Arábia, e o dia também é sempre tão quente que faz com que a gente se sinta tão bem.

Tem um belo luar e orgias demais. Quem se distrair pode até cair e ficar para trás.

Esta visão das orgias no mundo árabe praticamente se extinguiu do cinema após a ênfase no mundo religioso muçulmano, o qual tal ato é inconcebível, abordaremos este assunto adiante. Retomando a música do desenho Aladdin, na versão em espanhol da Espanha não há o verso sobre a mutilação, mas foi inserido o fator religioso (matar em nome de Alá) e sobre a lei da região:

Eu venho de onde a data é indicada. E os nômades bebem chá. E se eles não gostam de você lá, encomendarão a Alá. É difícil, eu sei, e daí?

$[\ldots]$

Se você vai para a Arábia, você não deve esquecer que lá há outra lei. Você deve atender se você quer viver.

Também há na versão em espanhol para América Latina a frase sobre a mutilação:

Eu venho de um lugar, uma terra inigualável onde você vê passar caravanas. E se eles não gostam de você lá, eles vão te mutilar. Essa barbárie! Mas este é o meu lugar.

[...]

Arábia é como noite e dia, calor intenso, eu não vi nada pior, tudo pode acontecer. 
Na versão em português, a referência às orgias no mundo árabe não é algo novo. Por séculos essa imagem se perpetuou no imaginário ocidental. A dança do ventre e o harém são vistos geralmente como parte de toda a cultura árabe, sendo ambos com elevado grau de erotismo de acordo com a visão ocidental. Ao citar as orgias, o autor apenas retomou este imaginário já praticamente cristalizado na mídia ocidental com os relatos dos viajantes europeus em terras árabes, entre os séculos XVIII e XIX. Aos que não viajavam, a imagem dos povos árabes estava estritamente relacionadas aos relatos dos viajantes.

Visitantes europeus a países islâmicos ficavam intrigados pelo que sabiam ou, mais precisamente, pelo que ouviram acerca do sistema do harém, e alguns deles falam com uma inveja mal disfarçada e mal informada do que imaginam serem os direitos e privilégios de um marido e chefe de família muçulmano (LEWIS, 2002, p.78).

No cinema são vastos os exemplos desta visão de árabes entregues à luxúria, ricos e intolerantes. O documentário Filmes ruins árabes malvados aponta vários trechos de filmes produzidos neste sentido. Destacamos o filme, de 1981, Cannonball Run 2, que de forma cômica retrata este estereótipo que descrevemos acima.

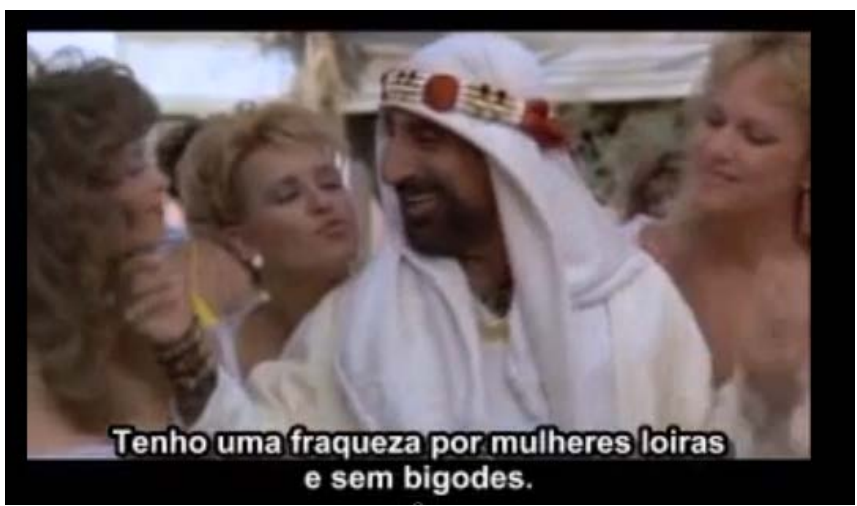

Figura 1: Frame do filme Cannonball Run 2 (1981) 


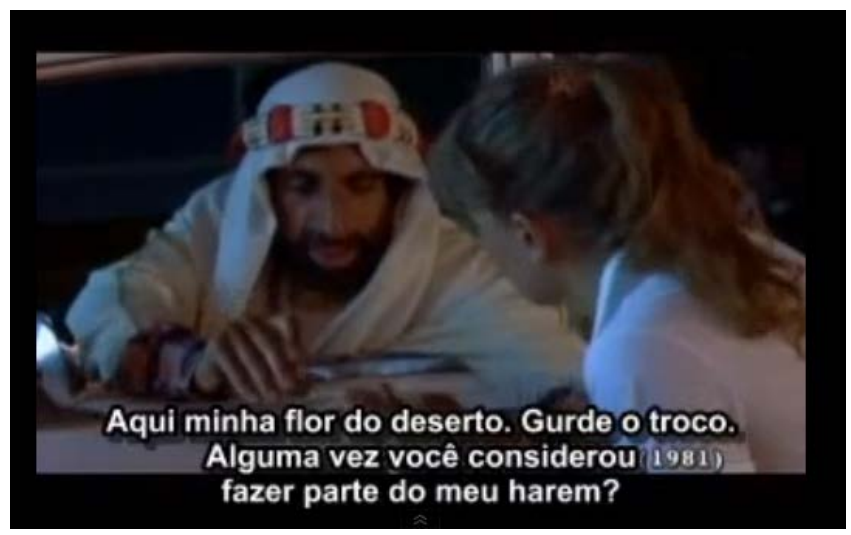

Figura 2: Frame do filme Cannonball Run $2(1981)^{6}$

A imagem do harém e da vida escrava das mulheres no Oriente Médio é recorrente no pensamento ocidental. No entanto, além do sistema de harém ser diferente de acordo com a sociedade inserida, a mulher também possuía certa liberdade secular de acordo com o grau de abertura concedido a ela:

A reclusão do harém não significava que a mulher era totalmente excluída da vida. Dentro dos aposentos femininos das grandes famílias, em visitas umas às outras, nas casas de banho públicas, que eram reservadas para as mulheres em momentos especiais, e nas celebrações de casamentos ou nascimentos de filhos, as mulheres encontravamse e mantinham uma cultura própria (HOURANI, 2006, p.176).

Com o tempo, a imagem feminina árabe passou de mulher do harém ou da dança do ventre para a mulher de burca e totalmente subjugada. Evidentemente, em alguns grupos mais radicais, a mulher passou a ser uma propriedade do homem sem grande liberdade de escolha. Mas isso não é um fato pertencente a todas as famílias muçulmanas e, muito menos, presente no mundo muçulmano anteriormente ao movimento fundamentalista islâmico. Na verdade, o islamismo, por muitas vezes, promoveu maior segurança às mulheres se comparado aos tempos pré-islâmicos nas sociedades árabes, conforme comenta Albert Hourani:

60 frame captado contém um erro ortográfico na legenda em português. Onde se lê "gurde o troco", leia-se "guarde o troco". 
O Corão afirmava em termos claros a igualdade essencial de homens e mulheres: "O justo, homem ou mulher, sendo um dos crentes entrará no Jardim”. Também ordenava a justiça e a bondade no trato entre muçulmanos. Parece provável que suas cláusulas em relação ao casamento e à herança desse às mulheres uma posição melhor do que tinham na Arábia pré-islâmica (HOURANI, 2006, p.176).

Percebemos que vários filmes produzidos no Ocidente representaram árabes cheios de estereótipos antigos: mulheres no harém, árabes milionários ou extremamente pobres. Resumindo de uma forma superficial, poderíamos dizer que a dança do ventre e os sheiks do petróleo eram, basicamente, o que a população ocidental conhecia sobre o Oriente. Após a Guerra do Golfo, essas imagens foram gradativamente substituídas por um estereótipo mais violento, reflexo dos conflitos armados que aumentaram na região após as intervenções norte-americanas.

Por outro lado, também temos a construção da imagem sobre o Ocidente produzida nos países árabes. As primeiras impressões sobre a interação Oriente e Ocidente entre os séculos XVII e XIX estão bem representadas nos relatos dos viajantes. Lewis fornece um exemplo, um relato de um turco que visitou Viena em 1665. O turco Evliya Çelebi foi um famoso escritor e desempenhava um papel diplomático entre os Estados:

Neste país vi um espetáculo extraordinário. Sempre que o imperador encontra uma mulher na rua, se está a cavalo, faz seu animal parar e deixa-a passar. Se o imperador está a pé e encontra uma mulher, detém-se numa postura de polidez. A mulher saúda o imperador, que então tira o chapéu da cabeça para lhe mostrar respeito [...] Neste país e em geral nas terras infiéis, as mulheres têm precedência. São honradas e respeitadas por amor à Mãe de Deus. (LEWIS, 2002, p.77)

O estranhamento de Evliya neste relato vai além do respeito aparente partindo de uma autoridade (homem) para uma mulher. Também devemos destacar o fato de entrar em questão o termo Mãe de Deus. Partindo do ponto de vista muçulmano esse ponto da teologia católica cristã é inconcebível.

Outro relato presente na obra de Lewis é de autoria de um embaixador otomano que visitou Paris em 1806: 
Nos banquetes europeus muitas mulheres estão presentes. As mulheres sentam-se à mesa enquanto os homens sentam-se atrás delas, observando como animais famintos as mulheres comerem. Se as mulheres se apiedam deles, dão-lhes alguma coisa para comer. Se não os homens ficam com fome (LEWIS, 2002, p.79).

Muito nos estranha tal relato de uma supremacia total das mulheres sobre os homens. Sabemos que na história ocidental, principalmente neste período, a mulher não possuía grandes liberdades ou tamanha autoridade sob os homens a ponto de deixá-los com fome em um banquete. Entretanto, este relato não é mais improvável que os relatos ocidentais sobre o que se passava nos haréns árabes.

Desde o início, a recepção do Ocidente no Oriente Médio ficou marcada por uma profunda ambivalência. Por um lado, houve admiração pela tecnologia e pelas indústrias europeias, ferramentas eficientes para subjugar inimigos. Isso conduzia a um desejo de imitar a ciência e as técnicas do Ocidente. Por outro lado, o Ocidente despertou repugnância (DEMANT, 2004, p.81).

Por fim, outro exemplo deste estranhamento cultural entre Oriente e Ocidente, é um relato de Sayyid Qtub - um egípcio que estudou nos Estados Unidos - publicado no jornal Al-Risala em 1951:

O americano é primitivo em seu gosto artístico, tanto no que ele gosta de arte e em seus próprios trabalhos artísticos. Jazz "música" é sua música preferida. Esta é a música que os negros inventaram para satisfazer as suas inclinações primitivas, assim como seu desejo de ser barulhento, por um lado e para excitar as tendências bestiais, por outro. O norte-americano de intoxicação em "jazz", a música não chega ao seu cumprimento integral até a música é acompanhada por canto que é tão grosseiro e desagradável como a própria música. Enquanto isso, o ruído dos instrumentos e das vozes monta, e soa nos ouvidos a um grau insuportável. A agitação da multidão aumenta, e as vozes de aprovação, e as palmas das mãos no anel contínuo, aplausos veementes de todos, mas ensurdece os ouvidos. (Tradução nossa) ${ }^{7}$

Com o acirramento das disputas ideológicas entre Ocidente (Estados Unidos e Europa) e o mundo muçulmano no século XX, a

7 Fonte: Hudson Institute, disponível em: <http://www.currenttrends.org/research/detail/ said-qutb-on-the-arts-in-america> Acesso em 06/12/2010. Traduzido do árabe para inglês por Daniel Burns 
representação do mundo ocidental também passou a ser mais violenta, sendo os Estados Unidos o grande alvo da mídia presente nos países muçulmanos.

Temos alguns exemplos extremados, no documentário Obsession: Radical Islam's War Against the West ${ }^{8}$. Destacamos que tais vídeos e pronunciamentos não são compartilhados em todos os países predominantementes muçulmano. Neste documentário podemos analisar algumas propagandas realizadas pelo governo iraniano na televisão e alguns discursos na TV iraquiana. Os dados foram coletados e traduzidos pelo The Middle East Media Research Institute (MEMRI) e utilizados no documentário.

Em primeiro lugar, destacamos uma utopia divulgada no Canal 1 iraniano que diz: "Um mundo sem América":

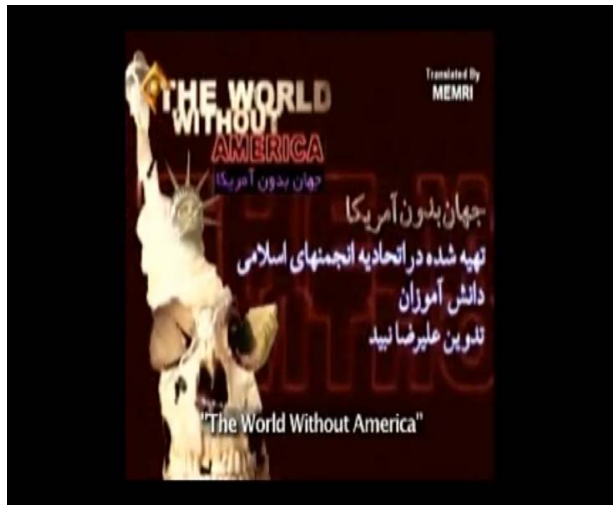

Figura 3: Frame da propaganda do governo iraniano no Canal 1

O mesmo símbolo norte-americano - a Estátua da Liberdade - é apresentada em um mar de sangue na Irinn TV.

8 Obsession: Radical Islam's War Against the West, 2005, 75min. 


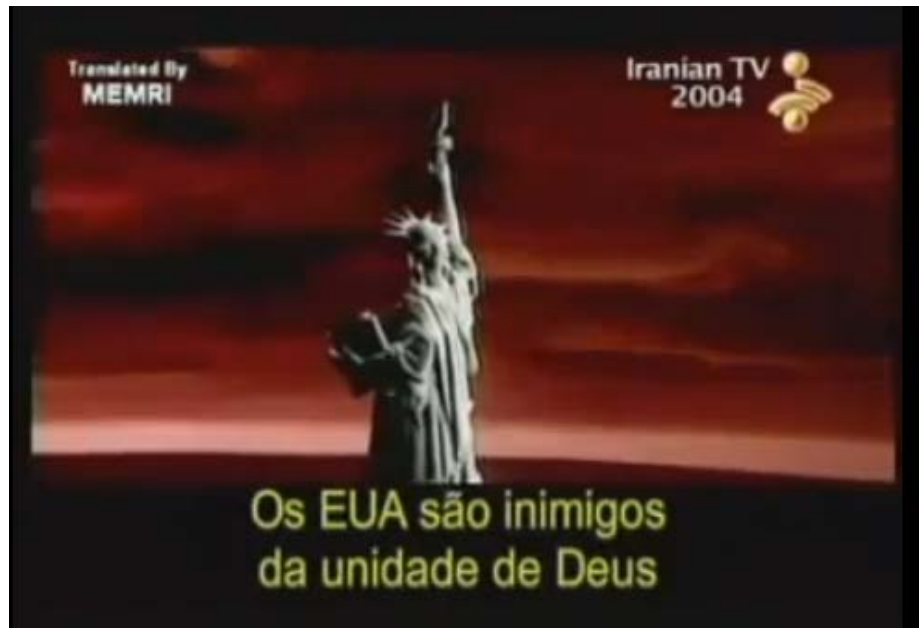

Figura 4: Frame da propaganda do governo iraniano na Irinn TV

Até mesmo um programa humorístico da Abu-Dhabi TV, nos Emirados Árabes, apresenta judeus que ao invés de beberem vinho precisam beber sangue árabe. Neste caso, a fala não foi traduzida pelo MEMRI, utilizamos a tradução do próprio documentário Obsession.

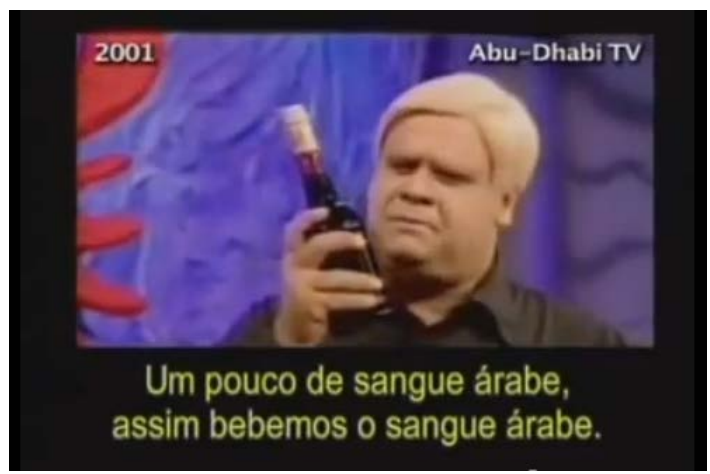

Figura 5: Frame do programa humorístico da TV Abu-Dhabi

Evidentemente, este programa de comédia transmitido na TV não se distancia muito da realidade dos filmes de Hollywood que por muitos anos apresentaram ao mundo ocidental a imagem distorcida e generalizada do árabe e do muçulmano. 
Complementando nossa análise, apresentaremos dois discursos veiculados nos canais de televisão do Oriente Médio. Um discurso transmitido na rede iraquiana e outro na rede iraniana.

Americanos, seu presidente, ingleses e seus seguidores. Sionistas, os dissidentes podres da entidade. Alá é maior. Se Alá permitir a nação de Maomé até as pedras dirão: muçulmano há um judeu atrás de mim, venha e corte sua cabeça. E nós cortaremos a cabeça por Alá, por Alá cortaremos. Alá é maior. ${ }^{9}$

Eles vieram lutar contra o Iraque. Então, eles vieram lutar contra o Islã. Portanto, todo muçulmano ou homem honrado não-muçulmano deve ficar contra americanos, ingleses e israelenses e colocar seus interesses em risco onde estiverem. ${ }^{10}$

Estes discursos certamente são observados por muitos muçulmanos da região. Isso, atrelado a um regime autoritário que inibe a imprensa, faz com que as pessoas destes países que não possuem outro canal de informação aceitem este fato como plena realidade, tornando alguns extremamente hostis ao Ocidente.

Por outro lado, os filmes de Hollywood continuam a reafirmar os estereótipos sobre mundo árabe que passam a ser assimilados pela sociedade. Após os atentados ao World Trade Center, em 11 de setembro de 2001, percebemos nitidamente um aumento no número de produções cinematográficas que abordam o terrorismo como tema principal.

O Guia cultural do Jornal A Folha de S. Paulo, de março de 2006, também comenta o terrorismo representado em obras cinematográficas. Segundo Sandro Macedo, que escreveu para a publicação, os documentários estariam em sintonia com os noticiários internacionais. Em 2006, o festival de documentários “É Tudo Verdade" também foi um indicativo deste aumento do tema terror e seu reflexo no cinema.

9 Discurso feito pelo Shaykh Bakr al-Samarra'i transmitido pela Tv iraquiana em fevereiro de 2003. Disponível em : <http://www.youtube.com/watch?v=AFAkmsszTD8>. Acesso em $03 / 07 / 2014$.

10 Discurso feito pelo Ayatollah Ahmad Jannati transmitido pela TV iraniana. Disponível em: Obsession: Radical Islam's War Against the West, 2005. Ahmad Jannati é um líder politico e religioso do Irã. 


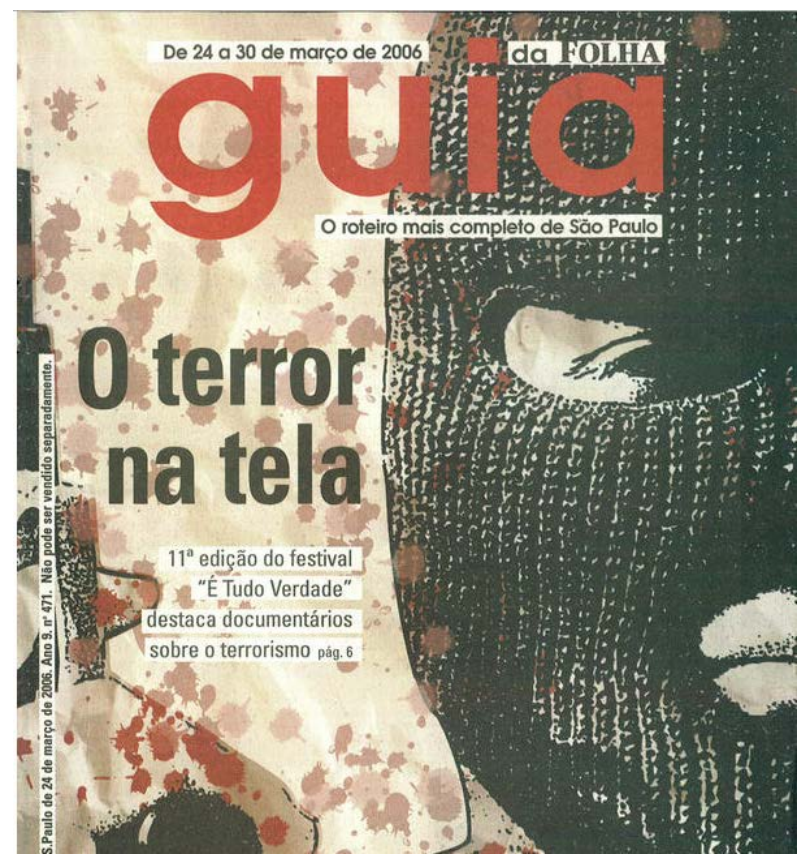

Figura 6: Capa do Guia Folha de S. Paulo

\section{A cobertura jornalística}

Além da produção audiovisual transmitida pela televisão ou nas salas de cinema, também devemos destacar as construções imaginárias sobre "o outro" que ecoam na mídia impressa. Diferentemente do entretenimento audiovisual que apresenta, por muitas vezes, estereótipos "prontos", a mídia impressa com o objetivo de levar informação, pode fornecer indiretamente subsídios para perpetuação destes estereótipos já consolidados.

Ao mencionarmos o noticiário internacional, também devemos destacar que a cobertura jornalística por muitas vezes é superficial. Em eventos internacionais o custo para gerar informação é um dos motivos para que os noticiários não se aprofundem no tema. Outro ponto que colabora para essa superficialidade é o desinteresse do leitor em assuntos que demandam maior reflexão. Segundo Jacques A. Wainberg (2005), as pessoas se aproveitam de atalhos mentais na tentativa de sistematizarem os fatos, atalhos que não exigem a compreensão dos fatos primários que desencadearam um evento. O que tornará este fato importante e verdadeiro para o leitor não será a justificativa 
pautada em dados e contextos, mas sim a quantidade de repetições de matérias com a mesma temática. Este problema reflete na mídia impressa no Brasil, uma vez que, boa parte das notícias internacionais publicadas são adquiridas através de fontes internacionais. Para exemplificar este fato, Isabelle Somma Castro em sua tese analisou as publicações sobre Oriente Médio entre o ano de 2001 e 2002, levando como marco divisor o dia 11 de setembro - dia dos atentados terroristas ao World Trade Center e ao Pentágono. Os jornais analisados foram Folha de S. Paulo (FSP) e O Estado de S. Paulo (OESP):

Comparação dos resultados de 2001 e 2002 na FSP

\begin{tabular}{|c|c|c|c|c|c|c|}
\hline \multirow{2}{*}{ Assunto } & \multicolumn{2}{|c|}{2001} & \multicolumn{2}{|c|}{2002} & \multicolumn{2}{|c|}{ Diferença } \\
\hline & $\begin{array}{l}\text { Número de } \\
\text { textos }\end{array}$ & $\begin{array}{l}\% \text { do } \\
\text { total }\end{array}$ & $\begin{array}{l}\text { Número } \\
\text { de textos }\end{array}$ & $\begin{array}{l}\% \text { do } \\
\text { total }\end{array}$ & $\begin{array}{l}\text { No número } \\
\text { de textos }\end{array}$ & $\begin{array}{l}\text { Na participação } \\
\text { no total (pp. })^{*}\end{array}$ \\
\hline Palestina//srael & 43 & 34,4 & 292 & 71,04 & +249 & $+36,64$ \\
\hline Macedônia & 25 & 20 & 0 & 0 & -25 & -20 \\
\hline Afeganistão & 15 & 12 & 41 & 9,97 & +26 & $-2,03$ \\
\hline Iraque & 7 & 5,6 & 23 & 5,59 & +16 & $-0,1$ \\
\hline Subtotal & 90 & 72 & 356 & 86,61 & +266 & $+14,61$ \\
\hline Outros & 35 & 28 & 55 & 13,38 & +20 & $-14,62$ \\
\hline TOTAL & 125 & 100 & 411 & 100 & +286 & $+69,58$ \\
\hline \multicolumn{7}{|l|}{ Enfoque } \\
\hline Violência & 76 & 60,8 & 198 & 48,17 & +122 & $-12,63$ \\
\hline Cultura & 8 & 6,4 & 8 & 1,94 & $=$ & $-4,46$ \\
\hline \multicolumn{7}{|l|}{ Origem } \\
\hline $\begin{array}{l}\text { Fontes } \\
\text { Internacionais }\end{array}$ & 98 & 78,4 & 236 & 57,42 & +138 & $-20,98$ \\
\hline
\end{tabular}

${ }^{*}$ Em pontos percentuais

Tabela 1: (CASTRO, 2007, p.113)

Comparação dos resultados de 2001 e 2002 em OESP

\begin{tabular}{|c|c|c|c|c|c|c|}
\hline \multirow[b]{2}{*}{ Assunto } & \multicolumn{2}{|c|}{2001} & \multicolumn{2}{|c|}{2002} & \multicolumn{2}{|c|}{ Diferença } \\
\hline & $\begin{array}{l}\text { Número de } \\
\text { textos }\end{array}$ & $\begin{array}{l}\% \text { do } \\
\text { total }\end{array}$ & $\begin{array}{l}\text { Número } \\
\text { de textos }\end{array}$ & $\begin{array}{l}\% \text { do } \\
\text { total }\end{array}$ & $\begin{array}{l}\text { No número } \\
\text { de textos }\end{array}$ & $\begin{array}{c}\text { Na participação } \\
\text { no total (pp. })^{*}\end{array}$ \\
\hline Palestina/Israel & 48 & 28,57 & 323 & 69,76 & +275 & $+41,19$ \\
\hline Macedônia & 25 & 14,88 & 0 & 0 & -25 & $-14,88$ \\
\hline Afeganistão & 12 & 7,14 & 54 & 11,66 & +42 & $+4,52$ \\
\hline Iraque & 6 & 3,57 & 44 & 9,50 & +38 & $+5,93$ \\
\hline Subtotal & 91 & 54,16 & 421 & 90,92 & 330 & $+36,76$ \\
\hline Outros & 77 & 45,83 & 42 & 9,07 & -35 & $-36,76$ \\
\hline TOTAL & 168 & 100 & 463 & 100 & +295 & $+63,71$ \\
\hline \multicolumn{7}{|l|}{ Enfoque } \\
\hline Violência & 79 & 47,02 & 181 & 39,09 & +102 & $-7,93$ \\
\hline Cultura & 7 & 4,16 & 9 & 1,94 & +2 & $-2,22$ \\
\hline \multicolumn{7}{|l|}{ Origem } \\
\hline $\begin{array}{l}\text { Fontes } \\
\text { Internacionais }\end{array}$ & 139 & 82,73 & 305 & 65,87 & +166 & $-16,86$ \\
\hline
\end{tabular}

Tabela 2 : (CASTRO, 2007, p.113) 
Por meio deste estudo, percebe-se um alto volume percentual de notícias, sobre o Oriente Médio, que são elaboradas por fontes internacionais. Além disso, o enfoque dos temas recai sobre a violência, isso é presente nos dois jornais. Outro ponto interessante é sobre o problema geográfico, pois mesmo após os atentados e as intervenções militares no Afeganistão e no Iraque, os dois jornais ampliaram a publicação de matérias sobre o conflito Israel e Palestina, fato que pode gerar certa generalização geográfica e generalização sobre os motivos dos conflitos. Ao falarmos de terrorismo promovido por pessoas de outros países, a falta deste conhecimento geográfico atrapalha o entendimento sobre o tema. Wainberg (2005) comenta que quanto mais distante se vive do terrorismo, menor compreensão há sobre o fato. Sem compreensão dos acontecimentos, o terrorismo passa a ser visto como um ato sem lógica e motivações, tornando-se algo totalmente desconhecido e imprevisto para boa parte da população, o que incentiva a cultura do medo.

$\mathrm{O}$ medo do desconhecido ajuda a alimentar a ideia de caos. $\mathrm{O}$ discurso do terrorismo reforça essa intenção, justificada segundo um olhar que é diferente do que foi atacado. O terrorismo provoca a sensação de impotência e instabilidade em todos os atingidos. (PAEIRO, 2012, p.33)

Mediante ao medo vários reflexos podem surgir, como a xenofobia e as perseguições étnicas e religiosas. Por isso, algo que aparamente é inofensivo como filmes e desenhos, podem conter mensagens poderosas no campo simbólico da sociedade.

\section{Considerações finais}

Nesta breve análise sobre a construção da imagem do "outro", percebemos que isso é reflexo de um processo histórico. Além da literatura e termos já cristalizados sobre este "outro", temos também o papel da mídia presente tanto no Ocidente quanto no Oriente. Muitas vezes, devido ao apego da mídia nos casos extremos de crueldades presentes no Ocidente e no Oriente, ambos se enxergam como um perigo que deve ser combatido ou modificado. Said, além de criticar os estudos produzidos na academia por europeus e norte-america- 
nos (chamando de sabedoria belicosa), também aponta para outros fatores que acentuam o preconceito ocidental contra o Oriente.

Toda essa sabedoria belicosa é acompanhada pelas onipresentes CNNs e Foxs deste mundo, juntamente com a quantidade mirífica de emissoras de rádio evangélicas direitistas, além de incontáveis tablóides e até jornais de porte médio, todos reciclando as mesmas fábulas inverificáveis e as mesmas vastas generalizações com o propósito de sacudir a "América" contra o diabo estrangeiro. (SAID, 2007, p.16).

Said também comenta que boa parte dos debates sobre o terrorismo vinculados à religião muçulmana promove apenas a polêmica sobre os fatos, sem levar em conta um trabalho de aproximação ou de melhor compreensão sobre as diferentes culturas:

Quando alguém se baseia em publicistas, intelectuais e jornalistas como Charles Krauthammer, Sergi Stankevich e Bernard Lewis, a argumentação já é tendenciosa em favor do conflito e da polêmica, em vez da verdadeira compreensão e do tipo de cooperação entre os povos de que nosso planeta necessita (SAID, 2003, p.318).

Diante deste ambiente propenso ao conflito, um clima de insegurança torna-se presente em boa parte da população. Surge, então, o momento adequado para o discurso político promover segurança a seu povo. $\mathrm{O}$ medo promovido por tais representações serve como instrumento para que extremistas e políticos defendam seus interesses e conquistem simpatizantes. "O medo torna o governante, a pretexto de proteger seus súditos de ameaças externas ou internas, absoluto em seu poder" (KEHL, 2007, p.95).

Este é o medo que afasta as nações e as culturas, promovendo um choque cultural fomentado pelos conceitos distorcidos sobre o "outro". Evidentemente, haverá sempre percepções da realidade e valores diferentes entre toda a humanidade, porém a promoção do medo em defesa do status quo tem demonstrado insucesso na história. Foram criados novos "muros" de preconceitos e muros reais na tentativa de nos proteger. Este fato foi destacado pelo autor Mia Couto na conferência de Segurança Internacional em Estoril no ano de 2011:

Há muros que separam nações, há muros que dividem pobres e ricos, mas não há hoje no mundo um muro que separe os que têm medo dos que não têm medo. Sob as mesmas nuvens cinzentas 
vivemos todos nós, do Sul e do Norte, do Ocidente e do Oriente. Citarei Eduardo Galeano acerca disto, que é o medo global, e dizer: os que trabalham têm medo de perder o trabalho; os que não trabalham têm medo de nunca encontrar trabalho; quando não têm medo da fome têm medo da comida; os civis têm medo dos militares; os militares têm medo da falta de armas e as armas têm medo da falta de guerras e, se calhar, acrescento agora eu, há quem tenha medo que o medo acabe ${ }^{11}$.

Por fim, Couto finaliza seu discurso citando velhos monstros do mundo Ocidental: Os chineses, Nelson Mandela e o comunismo:

Esses fantasmas tiveram o fim de todos os fantasmas: morreram quando morreu o medo. Os chineses abriram restaurantes à nossa porta, os ditos terroristas são hoje governantes respeitáveis e Karl Marx, o ateu barbudo, é um simpático avô que não deixou descendência.

Este é um tema que as ciências humanas e os estudos sobre a mídia podem colaborar com novas perspectivas, e subsidiar novas interpretações sobre estes choques de construções no imaginário. O esforço intelectual acadêmico pode contribuir para uma mídia de melhor qualidade ou denunciá-la quando erros e generalizações são apresentados por ela para a população. Pois a comunicação através da mídia sempre será de grande importância para humanidade: "A comunicação sabidamente desempenha um papel fundamental na sociedade: o homem não vive sem comunicação" (RUDIGER, 2011, p.7). Cabe agora o aprofundamento do debate para a promoção de uma cultura de paz.

\title{
Referências
}

\begin{abstract}
ARMSTRONG, Karen. Em nome de Deus: Fundamentalismo no Judaísmo, Cristianismo e Islã. São Paulo: Companhia das Letras, 2001.
\end{abstract}

\section{CASTRO, Isabelle Somma. Orientalismo na imprensa brasileira: A apresentação de árabes e muçulmanos nos jornais Folha de S. Paulo e O Estado de S. Paulo antes e depois de 11/09/2001. Dissertação apre- sentada ao departamento de Letras da Universidade de São Paulo FFLCH-USP, 2007.}

11 Disponível em <https://www.youtube.com/watch?v=jACccaTogxE>. Acesso em 29/03/2015. 
DEMANT, Peter Robert. O Mundo Muçulmano. São Paulo: Contexto, 2004.

DREHER Martin N. Para Entender o Fundamentalismo. São Leopoldo: Sinodal, 2006.

HAMADA, Basnyuoni. The Arab image in the minds of western image-makers. In: The Journal of internacional Communication, V.4, $\mathrm{n}^{\circ} 1$, Sydney, Macquarie University, 2001.

HOURANI, Albert. Uma história dos povos árabes. São Paulo: Companhia das Letras, 2006.

KEHL, Maria Rita. Elogio ao Medo. In: NOVAES, Adalto. Ensaios sobre o Medo. São Paulo: Editora Senac, 2007.

LEWIS, Bernard. O que deu errado no Oriente? Rio de Janeiro: Jorge Zahar, 2002.

PAEIRO, Denise Cristina. Mídia e Terror: A construção da imagem do terrorismo no jornalismo. Tese de Doutoramento apresentado ao departamento de Semiótica na PUC-SP, 2012.

RAHMAN, Fazlur. Study of Islamic Fundamentalism. Oxford: One Word, 2003.

RUDIGER, Francisco. As Teorias da Comunicação. Porto Alegre: Penso, 2011.

SAID, Edward. Reflexões sobre o Exílio. São Paulo: Companhia das Letras, 2003.

SAID, Edward. O Orientalismo: o Oriente como invenção do Ocidente. São Paulo. Cia das Letras, 2007.

WAINBERG, Jacques A. Mídia e Terror: Comunicação e Violência Política. São Paulo: Paulus, 2005. 